\title{
BRACHYMITRION LACINIATUM (SPLACHNACEAE) REDISCOVERED IN SOUTH AMERICA
}

\author{
MARÍA J. CANO \& JUAN A. JIMÉNEZ
}

\begin{abstract}
Brachymitrion laciniatum (Spruce) A. K. Kop., previously only known from the type specimen collected by Richard Spruce in Ecuador in the mid-eighteenth century, has been rediscovered in South America and is reported for the first time in Peru. New data about its morphology are provided. The species is illustrated by the first time and its distribution mapped.
\end{abstract}

Key words: Bryophyta, distribution, Tayloria, South America, Peru

María J. Cano \& Juan A. Jiménez, Departamento de Biología Vegetal (Botánica), Facultad de Biología, Universidad de Murcia, Campus de Espinardo, E-30100 Murcia, Spain; e-mail: mcano@um.es

\section{INTRODUCTION}

The genus Brachymitrion Taylor comprises six species distributed in tropical Africa and the Neotropics (Koponen 1977; Goffinet 1999). According to Koponen (1977), it is characterized by few stomata in a short neck, hypophysis absent, differentiated opercula, exothecial cells walls evenly thickened, capsule not shortening when drying, peristome of 16 teeth that are erect or bent inward when mature and dry, united at their tips in pairs and with reticulate exostome teeth. Goffinet et al. (2004) treated Brachymitrion as a subgenus of Tayloria Hook., on the basis of a molecular study using two chloroplast loci (trnL-trnF region and the rps 4 gene); however, recent checklists and floras have treated this taxon at generic level (Allen 2002; O'Shea 2006; Churchill et al. 2009). In South America, four species have been reported: Brachymitrion cochabambae (Müll. Hal.) A. K. Kop., known from Mexico, Guatemala, Costa Rica and Bolivia (Koponen 1994; Allen 2002; Churchill et al. 2009), B. jamesonii Taylor, known from Tropical Africa, Mexico, Central America, and Bolivia, Colombia, Ecuador, Peru and Venezuela in South America (Koponen 1994; Churchill et al. 2000; Allen 2002; Churchill et al. 2009), B. moritzianum (Müll. Hal.) A. K. Kop., from Tropical Africa, Mexico, Central
America and in Bolivia, Ecuador and Venezuela in South America (Koponen 1994; Churchill et al. 2000; Allen 2002), and B. laciniatum Spruce from Ecuador (Churchill et al. 2000). This latter species was described by Richard Spruce in 1860 from a single collection of this author in the Monte Azuay (Spruce 1860) and had not been collected again. Thus, it appears as an extinct species in the red list of endemic plant of this country (LeónYánez \& Grandstein 2011).

Over the last several years we have been engaged in studies of the South American Pottiaceae (Cano 2008; Cano \& Gallego 2008; Cano et al. 2010a, b; Jiménez et al. 2012). Due to the scarcity of collections in this territory, we are conducting field work in unexplored areas mainly of the Andes (Cano 2003; Cano et al. 2008; Cano et al. 2011; Cano \& Jiménez 2012). These new collections are providing a better means to assess the variability of many species, which were previously only known from one or a few localities. In 2009, some Departments from Northern Peru (Cajamarca, La Libertad and Piura) were explored and about 550 specimens of bryophytes were collected. Among these collections, we found a specimen of Brachymitrion, which we identified as B. laciniatum (Spruce) A. K. Kop. This species has not been reported 
in Peru before and it has not been recorded in South America for 150 years. The new record is deposited at MUB and USM herbaria.

\section{RESULTS}

\section{Brachymitrion laciniatum (Spruce) A. K. Kop.}

Ann. Bot. Fenn. 14: 196. 1977. Tayloria laciniata Spruce, J. Linn. Soc., Bot. 5: 48. 1861. TYPE. Ecuador. [El Cañar] 'in sylva Llallaad pedem occid. monte Azuay', 2770 m, Spruce 467 [LECTOTYPE, designated by Koponen (1977): BM; ISOLECTOTYPES: FH, H, NY, S].

Plants medium-sized, forming loose tufts, bright green to yellowish green. Stems $1.5-2 \mathrm{~cm}$ tall, erect, sometimes forked below; hyalodermis differentiated, sclerodermis weakly differentiated, usually with 1-2 layers, central strand developed; axillary hairs $2-3$ cells, 100-125 $\mu \mathrm{m}$ long, with 1-2 quadrate to rectangular, reddish brown basal cells and one elongate, hyaline, becoming glutinous in age; rhizoids at base, reddish brown, papillose. Leaves remote below, more crowed above, erect to slightly twisted when dry, erect-spreading when wet, spatulate, $2.3-4.1 \times 0.9-1 \mathrm{~mm}$, flat; lamina unistratose; apex acute, apiculate; margins plane, strongly laciniate from the apex to $1 / 3$ base, laciniae 200-750 $\mu \mathrm{m}$ long; border not or scarcely differentiated by 1 row of more elongate and thicker-walled cells; base strongly decurrent; costa simple, ending well below the apex, in cross-section semicircular, 2 guide cells in 1 layer, ventral stereids in 2-4 rows, hydroids undeveloped, dorsal and ventral surface cells differentiated, smooth; upper and middle laminal cells hexagonal to long-rectangular, (50-)80-112 × 16-27 $\mu \mathrm{m}$, slightly thick-walled, not collenchymatous, smooth; basal cells hexagonal to long-rectangular, 61-115 × 19-24 $\mu \mathrm{m}$, slightly thick-walled, not porose, smooth; marginal cells long-rectangular, 105-154 × 8-16 $\mu \mathrm{m}$, thickwalled. Autoicous. Vaginula scabrous. Perichaetia terminal; perichaetial leaves slightly differentiated, with oblong to oblong-linear leaves, longer laciniae in the margins, and costa excurrent, 4-4.8 $\times 0.6-1.3 \mathrm{~mm}$. Setae $0.4-0.5 \mathrm{~mm}$ long, straight, yellowish, brown when mature. Capsule immersed, yellowish brown to brownish. Urns ovoid, 1.5-1.6 $\times 1-1.2 \mathrm{~mm}$; exothecial cells rectangular, 29-42 $\times 13-29 \mu \mathrm{m}$, thin-walled, slightly bulbing; stomata phaneroporous, restricted to the neck; peristome of 16 erect, lanceolate teeth, 550-600 $\mu \mathrm{m}$ long, brownish, perforated, outer surface densely papillose, inner surface densely papillose below, striate distally, trabeculate; operculum rostrate, $\mathrm{ca}$ 0.7-0.8 mm long. Calyptrae mitrate, 4-5 lobed, ca $1.2 \mathrm{~mm}$ long, scabrous. Spores $21-24 \mu \mathrm{m}$ in diameter, brownish, papillose.

NEW RECORD: PERU: Piura, pr. Ayavaca, Bosque de Cuyas, $4^{\circ} 35^{\prime} 59^{\prime \prime} \mathrm{S} 79^{\circ} 42^{\prime} 40^{\prime \prime} \mathrm{W}, 25$ June 2009, Cano \& Jiménez 5290 (MUB 32586, USM).

This new population was discovered in a cloud forest formation known as Bosque de Cuyas in north-eastern of Piura department. The forest covers an area of 600 hectares and it is one of the most intact forests in the region. The annual $1000 \mathrm{~mm}$ of rainfall is concentrated mostly from

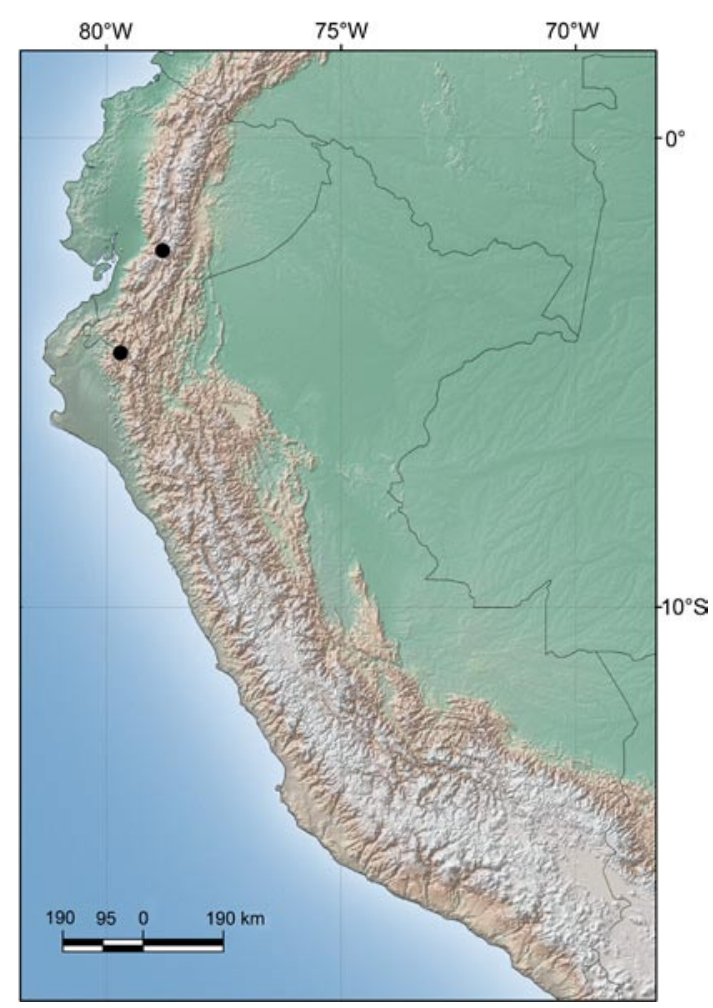

Fig. 1. Known distribution of Brachymitrion laciniatum (Spruce) A. K. Kop. 

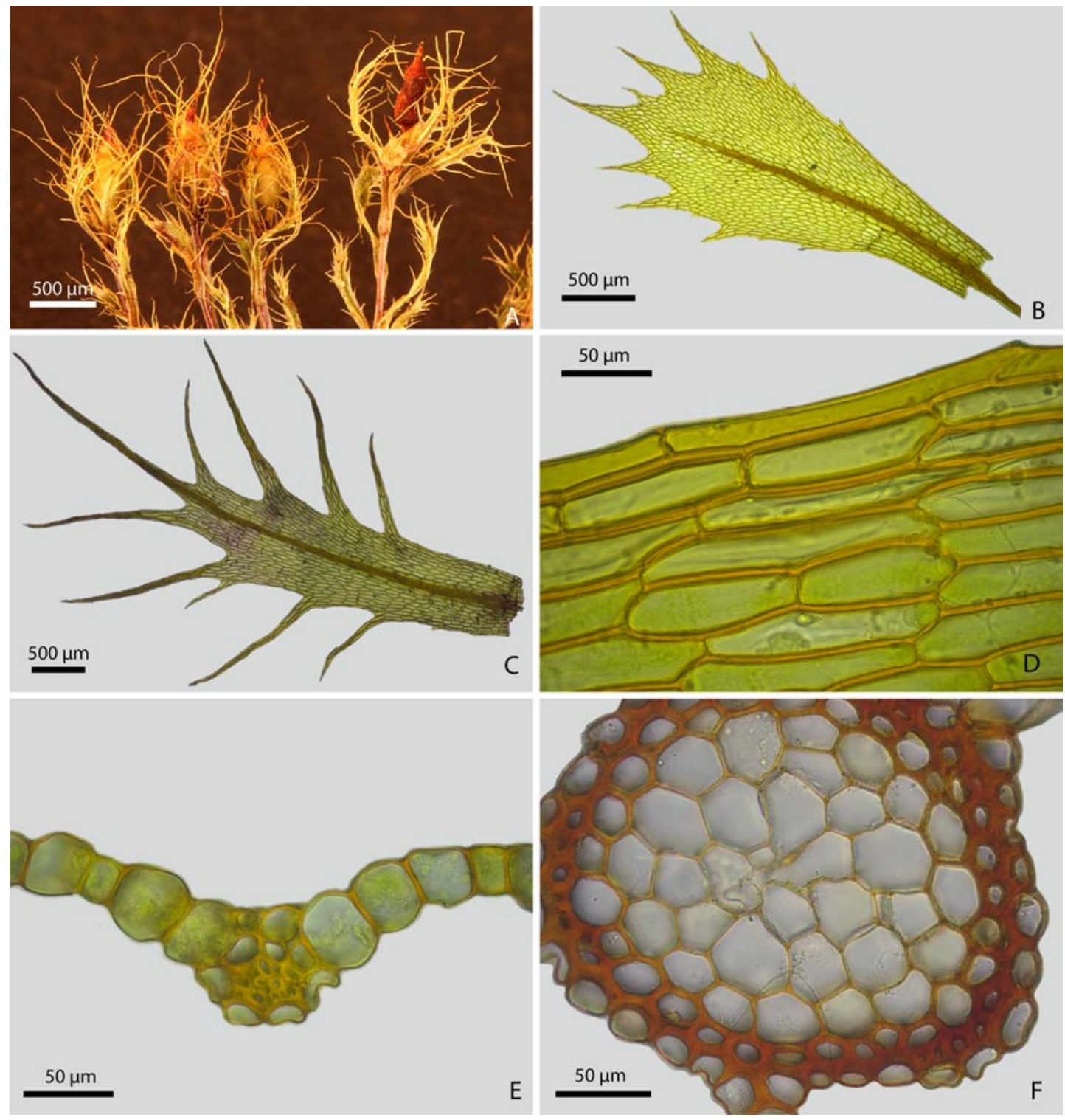

Fig. 2. Brachymitrion laciniatum (Spruce) A. K. Kop. A - habit, B - leaf, C - perichaetial leaf, D - middle laminal cells, E cross-section of the leaf, F - cross-section of the stem. All figures from Cano \& Jiménez 5290.

December to May (Kikuchi 2009). Here, Brachymitrion laciniatum was found epiphytic on a tree branch at $2520 \mathrm{~m}$ in elevation and the vegetation was composed mainly by species of Lauraceae, Melastomataceae, Myrsinaceae, Clusiaceae, Ericaceae and Arecaceae. In Fig. 1 the known distribution of the species is mapped.
Brachymitrion laciniatum can be easily distinguished in the field by the immersed, ovoid capsule surrounded by oblong to linear-oblong, and the strongly laciniate perichaetial leaves. Other diagnostic characters are the scabrous vaginula and calyptra, peristome of straight and brownish teeth, spatulate leaves, with margins strongly dentate 

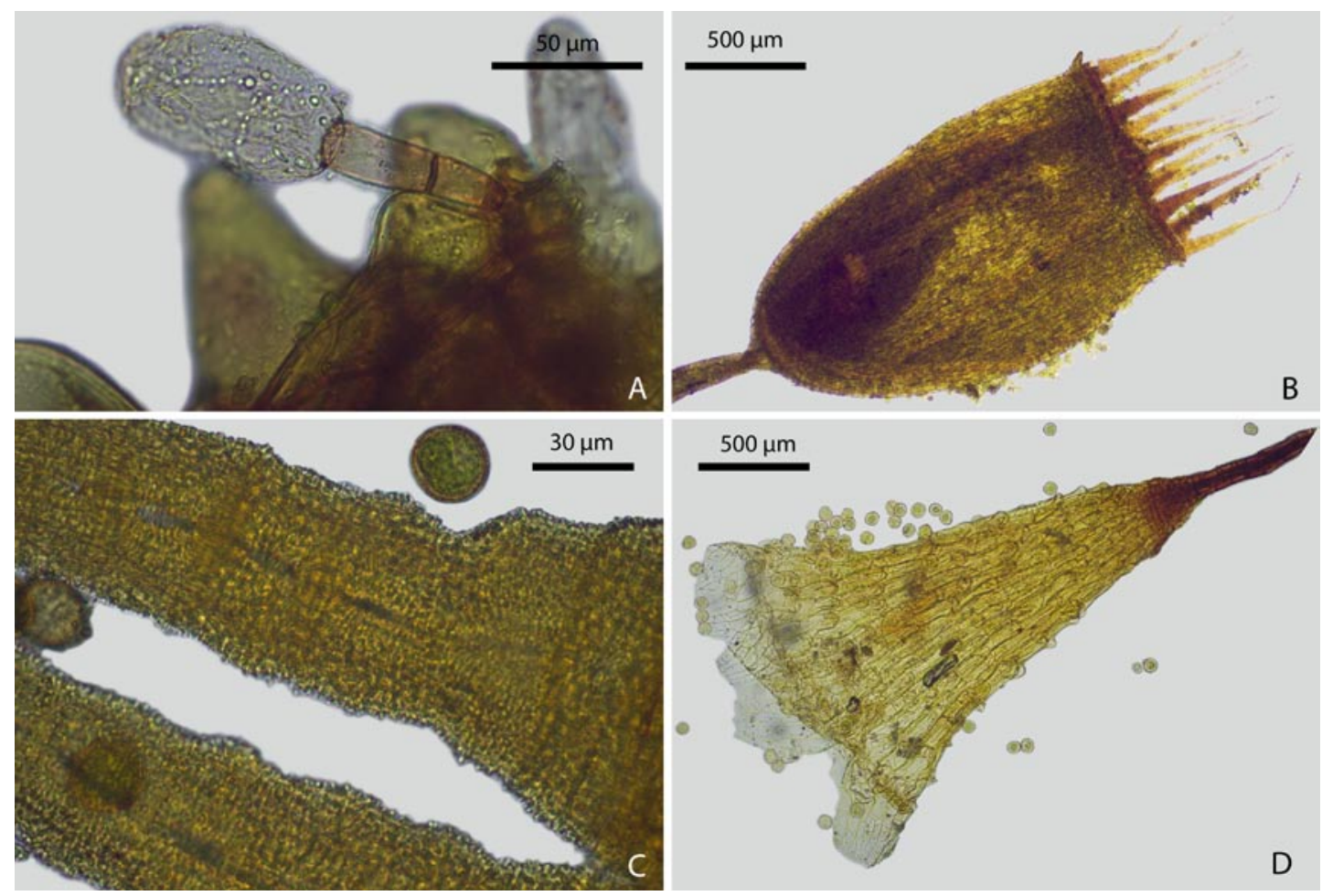

Fig. 3. Brachymitrion laciniatum (Spruce) A. K. Kop. A - axillary hair on vaginula, B - capsule, C - inner surface of peristome teeth, D - calyptra. All figures from Cano \& Jiménez 5290.

(laciniae up to $750 \mu \mathrm{m}$ ), perichaetial leaves slightly differentiated from vegetative, and marginal cells not or scarcely differentiated. Some of these characters such as the size of the laciniae, the scabrous calyptra, the shape and size of the marginal cells of the leaf or size of spores have not been provided before, because they were not described in Spruce (1860). The shape of the capsule is similar to the African B. immersum Goffinet, however, the latter species exhibits serrate to serrulate leaf margins with marginal cells hyaline, forming a conspicuous border. The only other species with more spinose leaf margins is B. moritzianum, which is distinguished from $B$. laciniatum by its leaf margins with shorter, reddish teeth, undifferentiated perichaetial leaves and exserted, cylindrical capsule. A key to the species of Brachymitrion was provided by Goffinet (1999). In Fig. 2 and 3, the diagnostic characters of this species are illustrated.
ACKNOWLEDGEMENTS. This research was carried out with financial support from the Spanish 'Ministerio de Ciencia e Innovación' (Project CGL2010-15959/BOS co-financed by FEDER and 'Ramón y Cajal subprogram' co-financed by the European Social Fund). We are very grateful to Asunción Cano from Museo de Historia Natural of Universidad Nacional Mayor de San Marcos (Lima, Peru) for assistance in our trip to Peru.

\section{REFERENCES}

Allen B. 2002. Moss flora of Central America, Part 2. Encalyptaceae-Orthotrichaceae. Monogr. Syst. Bot. Missouri Bot. Gard. 90: 1-699.

CANO M. J. 2003. New records and range extensions of some mosses in tropical areas of Chile. Trop. Bryol. 24: 15-20.

CANo M. J. 2008. Taxonomic revision of Hennediella Paris (Pottiaceae, Bryophyta). Bryophyt. Biblioth. 64: 1-142.

Cano M. J. \& Gallego M. T. 2008. The genus Tortula (Pot- 
tiaceae, Bryophyta) in South America. Bot. J. Linn. Soc. 156: $173-220$.

CANo M. J. \& JimÉneZ J. A. 2012. New records of Pottiaceae (Bryophyta) for Venezuela. Polish Bot. J. 57: 161-166.

Cano M. J., Jiménez J. A., Churchill S. P. \& Guerra J. 2008. New records of Pottiaceae (Bryophyta) for South America. Cryptog. Bryol. 29: 183-191.

CAno M. J., Jiménez J. A., Gallego M. T. \& Jiménez J. F. 2010a. Guerramontesia microdonta (Pottiaceae, Bryophyta) a new monotypic genus from South America. Syst. Bot. 35: 453-460.

CANO M. J., JimÉNEZ J. A. \& JiMÉNEZ J. F. 2010b. A systematic revision of the genus Erythrophyllopsis (Pottiaceae, Bryophyta). Syst. Bot. 35: 683-694.

CAno M. J., JimÉnez J. A. \& Guerra J. 2011. New records of Pottiaceae (Bryophyta) for Argentina and Bolivia. Nova Hedwigia 93: 165-176.

ChurChill S. P., GRIFFIN III D. \& MuÑOZ J. 2000. A checklist of the mosses of the tropical Andean countries. Ruizia 17: 1-203.

Churchill S. P., Sanjines N. \& Aldana C. 2009. Catálogo de las Briofitas de Bolivia: Diversidad, Distribución y Ecología. Missouri Botanical Garden \& Museo Noel Kempff Mercado, Santa Cruz de la Sierra.

GoFFINET B. 1999. Brachymitrion immersum (Splachnaceae, Musci), a new species from Cameroon. Bryologist 102: 108-111.

Goffinet B., Shaw A. J. \& Cox C. J. 2004. Phylogenetic inferences in the dung-moss family Splachnaceae from analyses of cpDNA sequence data and implications for the evolution of entomophily. Amer. J. Bot. 91: 748-759.

Jiménez J. A., CANo M. J. \& JimÉnez J. F. 2012. Taxonomy and phylogeny of Andina (Pottiaceae, Bryophyta): a new moss genus from the Tropical Andes. Syst. Bot. 37: 293-306.

KIKUCHI D. W. 2009. Terrestrial and understorey insectivorous birds of a Peruvian cloud forest: species richness, abundance, density, territory size and biomass. J. Trop. Ecol. 25: 523-529.

Koponen A. 1977. Tayloria subgen. Pseudotetraplodon, subgen. nov., and new combinations in Brachymitrion, Moseniella and Tayloria (Splachnaceae, Musci). Ann. Bot. Fenn. 14: 193-196.

Koponen A. 1994. Splachnales. In: A. J. Sharp, H. CRUM \& P. M. ECKEL (eds), The moss flora of Mexico. Mem. New York Bot. Gard. 69: 444-452.

LEÓN-YÁNEZ S., R. \& GRADSTEIN R. S. 2011. Briófitas. In: S León-YÁnez, R. VAlencia, N. Pitman, L. Endara, C. UlloA \& H. NAVARRETE (eds). Libro rojo de las plantas endémicas del Ecuador, $2^{a}$ edición, pp. 865-879. Publicaciones del Herbario QCA, Pontificia Universidad Católica del Ecuador, Quito.

O'SHEA B. J. 2006. Checklist of the mosses of sub-Saharan Africa (version 5, 12/06). Trop. Bryol. Res. Rep. 6: 1-252.

SPRUCE R. 1860. Mosses of the Amazon and Andes. J. Proc. Linn. Soc., Bot. 5: 45-51. 